\title{
Laparoscopic non-microsurgical tubal reanastomosis: A retrospective cohort study
}

\author{
Marije van de Water*, Jan Bosteels ${ }^{\dagger}$, Petra De Sutter* and Steven Weyers* \\ *Department of Obstetrics and Gynaecology, Ghent University Hospital, Ghent, and tDepartment of Obstetrics and \\ Gynaecology, Imelda Hospital, Bonheiden, Belgium
}

ABSTRACT Objective To determine the pregnancy rate achieved through laparoscopic tubal reanastomosis using only standard $5 \mathrm{~mm}$ laparoscopic instruments and standard suturing material.

Methods Data from 100 consecutive laparoscopic tubal reanastomosis procedures done between September 2002 and September 2010 were retrospectively analysed. All procedures were performed by the same surgeon using standard $5 \mathrm{~mm}$ laparoscopic instruments and with the placing of three or four sutures of standard polyglycan $4 / 0$ suturing material. The main outcome measures were: (intrauterine) pregnancy rate and live birth rate before and after 40 years of age, and tubal patency rate.

Results Six patients had no active child wish and six others were lost to follow-up, thus leaving 88 of 100 patients for evaluation. Fifty-eight of these conceived, giving a total pregnancy rate $(\mathrm{PR})$ of $66 \%$. The $\mathrm{PR}$ in women younger than 40 years was significantly greater than that achieved by those aged 40 or more ( $73 \%$ vs. $29 \%, p=0.001)$.

Conclusions Laparoscopic tubal reanastomosis with standard $5 \mathrm{~mm}$ laparoscopic instruments results in a satisfactory pregnancy rate.

K E Y W O R D S Tubal reanastomosis; Sterilisation reversal; Microsurgery; Laparoscopy

I N T ROD U C T I O N

Despite extensive counselling and the observance of strict criteria for tubal occlusion procedures, 1 to $5 \%$ of all sterilised women request sterilisation reversal at some point ${ }^{1,2}$. Most of the women concerned have proven their fertility.

From a health-economical point of view, tubal reanastomosis makes sense only if its results equal those of in vitro fertilisation (IVF) at a comparable or preferably lower cost. From an emotional and psychological point of view, initiating a pregnancy 'the old-fashioned way' is still favoured by most couples. Moreover, successful tubal sterilisation reversal may lead to several, successive conceptions while a successful IVF only yields one pregnancy at the time.

Different techniques of tubal repair have been described, such as open and laparoscopic microsurgery, conventional laparoscopy, and robot-assisted surgery ${ }^{3}$.

Correspondence: Steven Weyers, UZ Gent, De Pintelaan 185, B-9000 Gent, Belgium. Tel: + 329 2403793. Fax: + 32 9 2403831. E-mail: steven. weyers@ugent.be 
Advantages of the laparoscopic route as opposed to laparotomy include a shorter hospital stay and less post-operative pain. The main objectives of this observational study were to assess whether satisfactory pregnancy rates can be obtained by means of a non-microsurgical technique of laparoscopic tubal reanastomosis and whether there are significant differences between outcomes in women undergoing this intervention before or after the age of 40 .

\section{MATERIALS AND METHODS}

\section{Population}

In a large university hospital in Belgium, between September 2002 and September 2010, 112 women who had undergone a tubal sterilisation and who wished to become pregnant again submitted to a fertility exploration which included a pelvic ultrasound and a basal hormone assessment. The current partner's semen was analysed only if he had not fathered children before. Tubal reanastomosis was not considered in case of male factor infertility (according to the 1999 World Health Organization's criteria) or impending ovarian insufficiency (threshold level of basal FSH $>12 \mathrm{mIU} /$ $\mathrm{ml}$ ). A diagnostic laparoscopy was not part of the regular diagnostic work-up. Initially we did not exclude patients based on age but, since 2008, we exclude those older than 45. Patients were counselled about the total pregnancy rate, the risk of ectopic pregnancy and IVF as an alternative. A reanastomosis was performed if it appeared at laparoscopy that the remaining tubal length was at least $4 \mathrm{~cm}$. A Chlamydia-screening was not done routinely. Based on these criteria we refrained from carrying out a tubal reanastomosis in 12 patients: in three, due to the bad semen quality of their partner, and in the nine others because both tubes proved to be too severely damaged at laparoscopy. Over the aforementioned period of time 100 laparoscopic tubal reanastomoses were performed, all of which by the same surgeon (SW).

\section{Intervention}

The procedure was completed using classical $5 \mathrm{~mm}$ curved, not microsurgical, needle holders and 4/0 polyglycan threads $\left(\right.$ Vicryl ${ }^{\circledR}$, Ethicon, Johnson \& Johnson Medical BV, Dilbeek, Belgium). We slightly adapted the technique described by Barjot et al. ${ }^{4}$ First we carried out a hysteroscopically-guided, backward catheterisation of the proximal tubal stump. After laparoscopic excision of the occluded segment or of the scar tissue present in both stumps of the tube the catheter was guided into its distal part. We then closed the defect in the mesosalpinx with one stitch of polyglycan 4/0 and proceeded to reapproximate the proximal and distal parts of each Fallopian tube by means of two or three sutures of the same 4/0 material (at 6 and 12 o'clock, with sometimes an additional stitch at 3 or 9 o'clock) through the muscular layer and the serosa, all the while trying to avoid entering the tubal lumen. The catheters were removed at the end of the procedure. Surgery was planned as a one-day-clinicor one-night-stay intervention, and patients were never kept from their work for more than one week. Complications during surgery were rated grade 1 to 5 according to the Dindo-Clavien classification ${ }^{5}$.

A hysterosalpingography (HSG) was planned two months after surgery. Patency was defined as unhindered passage of the radio-opaque dye into the distal part of the Fallopian tube and the peritoneal cavity.

A clinical pregnancy was defined according to ICMART (International Committee for Monitoring Assisted Reproductive Technology ${ }^{6}$ as a pregnancy diagnosed by ultrasonographic identification of one or more gestational sacs or definitive clinical signs of pregnancy, and thus included ectopic pregnancy. The presence of multiple gestational sacs was accounted for as one clinical pregnancy.

\section{Statistical analysis}

For statistical analysis we resorted to $\operatorname{IBM}^{\circledR} \operatorname{SPSS}^{\circledR}$ Statistics Version 20. As the data were not normally distributed and hence not appropriate for 'parametric' tests, the Mann-Whitney $\mathrm{U}$ test was used; $p<0.05$ was considered significant.

\section{Ethical approval}

This retrospective cohort study was conducted in accordance with the Declaration of Helsinki and was approved by the ethical committee of the Ghent University Hospital.

\section{RE S U L T S}

All 100 patients had a minimal follow-up of 24 months; the latter's median duration was 64 months 
(standard deviation [SD]: \pm 24 ; range: 28-123). The mean age of the patients at the moment of surgery was 35.3 (SD: \pm 4.9 ; range: $26-48$ ) years. The median time elapsed between sterilisation and reanastomosis was 72 months (SD: \pm 50 ; range: 12-192). Methods of sterilisation were clips in 66 patients (66\%), Falope ring in 19 patients (19\%), and electrocoagulation in 15 patients $(15 \%)$. The mean operating time for the total group was 108 (SD: \pm 25 ; range: 45-260) minutes. In 14 of the 100 patients only a unilateral tubal reanastomosis was carried out. We encountered neither per- nor postoperative complications (Grade 1 to 5 according to Dindo et al. ${ }^{5}$ ), and never had to convert to a laparotomy.

Seventy-eight of the 100 (78\%) patients underwent a HSG. The total patency rate was 66\% (95 patent tubes out of the 145 that were evaluated) and 63 patients $(81 \%)$ had at least one patent tube on HSG. The patency rate for women who conceived was $76 \%$ (65 patent tubes out of the 86 tubes evaluated) and 43 (96\%) had at least one patent tube on HSG. The patency rate of those who did not conceive was 56\% (25 patent tubes out of the 45 tubes evaluated) and 17 $(68 \%)$ had at least one patent tube on HSG. The tubal patency rate in the group of women younger than 40 years was $67 \%$ (83 tubes out of the 124 which were evaluated) whereas in the group aged 40 years and more it was $59 \%$ (13 patent tubes out of the 22 tubes evaluated) $(p=0.525)$.

Six women had no further pregnancy desire after the laparoscopic reversal procedure. Despite repeated attempts, we did not succeed in accessing follow-up data about pregnancy with regard to six other women who had been referred to our department. We excluded these 12 subjects from the final analysis. Data from 88 women were thus available for the final analysis of the reproductive outcome after the laparoscopic tubal reversal procedure. The clinical pregnancy rate was $66 \%(58 / 88)$. Of all first pregnancies after tubal reanastomosis, 90\% (52/58) were intrauterine, giving a crude intrauterine pregnancy rate (IUPR) of 59\%. However, 21 of these first pregnancies (36\%) ended in a miscarriage; five of the patients concerned and one whose first pregnancy was ectopic had an ongoing gestation afterwards. In total, 12 women had more than one pregnancy after reversal, three of whom had two live births. The live-birth rate in the cohort of 88 women operated upon, whose data were available for analysis, was $42 \%(37 / 88)$ (Figure 1).
Since age is an important confounder in studies of human reproduction, we did a predefined subgroup analysis, and investigated the effect of age on the primary outcome. Two subgroups were defined based on the cut-off age of 40 years. There were clinically relevant and statistically significant differences between both subgroups. The clinical pregnancy rate was significantly higher in the age group below 40 years compared to women 40 years and older $(73 \%$ [54/74] vs. $29 \%$ [4/14], $p=0.001$; Figure 2$)$. The live-birth rate in women younger than 40 years was also significantly higher than among those 40 years and older $(49 \%$ [36/74] vs. $7 \%[1 / 14], p=0.005)$.

We conducted a sensitivity analysis for the primary outcome of clinical pregnancy to determine whether this conclusion would still stand if we would include the six women lost to follow-up and use the following paradoxical imputation strategy: all women lost to follow-up who were older than 40 would have been pregnant versus none of those aged less. The clinical pregnancy rates would then be $64 \%$ $(50 / 78)$ in the group of women younger than 40 years and $37.5 \%(6 / 16$ in those aged 40 years and more; these differences are still statistically significant $(p=0.017)$.

The two age groups did not significantly differ with regard to the occurrence of miscarriage (35\% [19/54] among the younger subjects vs. $50 \%[2 / 4]$ among the older ones, $p=0.65$ ).

The median time to pregnancy was five months (2-24 months) for the total group. For women under 40 years of age the median time to pregnancy was five months (2-24 months), while for those aged 40 years and more the median time to pregnancy was seven months (6-8 months).

To determine the benefit of tubal reanastomosis for our patients, we compared pregnancy rates achieved with those of patients with tubal factor infertility treated by other means in our own centre of reproductive medicine. Between 2003 and 2012, in total, 1276 IVF cycles were started for such women, leading to 299 clinical pregnancies and 209 deliveries, thus yielding a total PR of $23 \%$ and a live birth rate of $16 \%$. In women aged less than 40 years, 1033 cycles were started, leading to a PR of $25.5 \%$ and a live-birth rate of $19 \%$. Women aged 40 and older had 243 started cycles, yielding a PR of $14 \%$ and a live-birth rate of $7 \%$. 


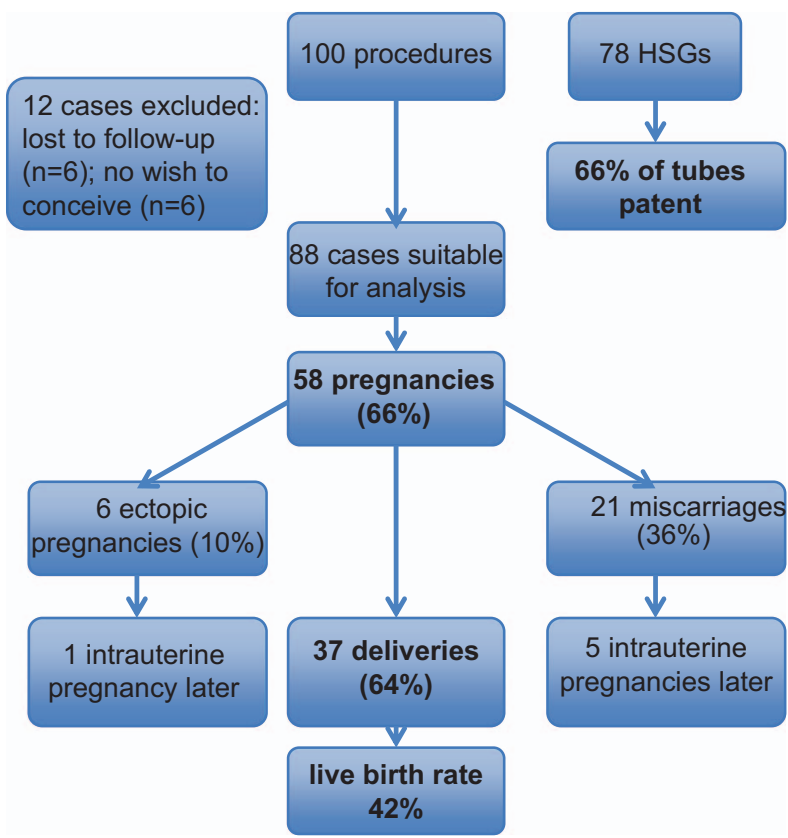

Figure 1 Flowchart of pregnancy results. HSG, hysterosalpingography.

\section{I S C U S S I O N}

\section{Results of other studies}

Reports pertaining to these techniques are scarce and rarely concern more than 30 patients (Table 1$)^{7-26}$.

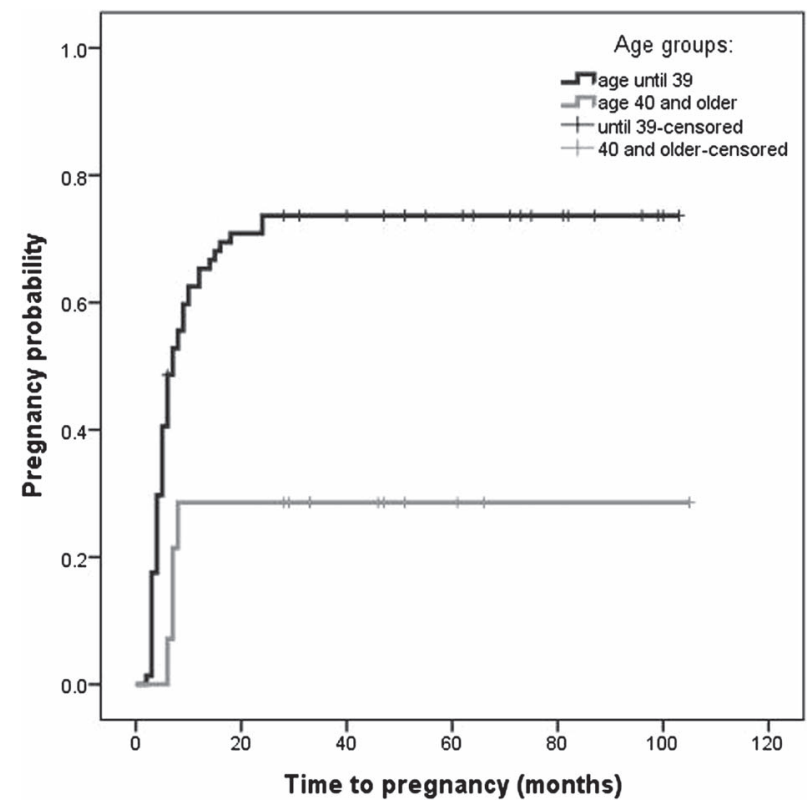

Figure 2 Kaplan-Meier curves of time to pregnancy among (i) women younger than 40 years; and (ii) those aged 40 years or more who underwent a laparoscopic tubal reanastomosis.
One series exceeding 100 patients was published in 1999 by Yoon et al. ${ }^{13}$. These authors approximated the mesosalpinx with a few stitches of polydioxanone $6 / 0$; they then placed four stitches of a 7/0 thread on the muscular layer of the Fallopian tube and at least four more of $6 / 0$ suture material on the serosa. They employed $3 \mathrm{~mm}$ laparoscopic microsurgical instruments and did not place tubal catheters. The total PR in this group of 202 patients was very high (85\%). The PR did not significantly differ by either method of sterilisation (Pomeroy, electrocoagulation, Faloperings), site of reanastomosis (although there was a trend towards better results when performing isthmoisthmic and isthmo-ampullar reanastomosis), and remaining length of the tube.

Around the same period, two French groups published on their experience with simplified techniques of tubal reanastomosis ${ }^{4,11}$. The total PR in these groups was lower (59\% and 36\%), which was possibly related to the smaller number of patients included. The effectiveness of Dubuisson's technique was demonstrated shortly afterwards when, resorting to this technique on a larger series of patients, another group achieved a PR of $73 \%{ }^{12}$.

Two retrospective studies compared the microsurgical technique via laparotomy to the minimally invasive laparoscopic approach. In 2001 Cha et al. described the results of tubal reanastomosis in 81 patients, of whom 
Table 1 Series of laparoscopic tubal sterilisation reversal procedures published from 1990 onwards.

\begin{tabular}{|c|c|c|c|c|c|c|c|}
\hline $\begin{array}{l}\text { First author, year, } \\
\text { reference number }\end{array}$ & Technique & $\begin{array}{l}\text { Number } \\
\text { of } \\
\text { patients }\end{array}$ & $\begin{array}{l}\text { Mean } \\
\text { age, } \\
\text { years }\end{array}$ & $\begin{array}{l}\text { Mean } \\
\text { operating } \\
\text { time, } \\
\text { minutes }\end{array}$ & $\begin{array}{l}\text { Total } \\
\text { pregnancy } \\
\text { rate, } \%\end{array}$ & $\begin{array}{l}\text { Intrauterine } \\
\text { pregnancy } \\
\text { rate, \% }\end{array}$ & $\begin{array}{l}\text { Abortion } \\
\text { rate, \% }\end{array}$ \\
\hline \multicolumn{8}{|l|}{ Without robot } \\
\hline Gauwerky $1990^{5}$ & $\begin{array}{l}\text { Microsurgical instruments } \\
\text { No catheters } \\
\text { Tissue glue }\end{array}$ & 12 & $\mathrm{NR}^{b}$ & NR & 42 & 60 & 0 \\
\hline $\begin{array}{l}\text { Trimbos-Kemper } \\
1990^{19}\end{array}$ & Microsurgical instruments & 78 & 41 & NR & 49 & 92 & 26 \\
\hline Reich $1993^{6}$ & $\begin{array}{l}\text { Regular laparoscopic } \\
\text { instruments } \\
\text { With/without catheter }\end{array}$ & 22 & NR & NR & 35 & NR & NR \\
\hline $\begin{array}{l}\text { Koh } 1995^{7} \\
\text { (congress abstract) }\end{array}$ & $\begin{array}{l}\text { Microsurgical instruments } \\
\text { No catheters }\end{array}$ & 31 & NR & NR & 71 & 95 & NR \\
\hline Yoon $1997^{8}$ & $\begin{array}{l}\text { Microsurgical instruments } \\
\text { No catheters }\end{array}$ & 49 & 33.5 & NR & 78 & 97 & 3 \\
\hline Dubuisson $1998^{9}$ & $\begin{array}{l}\text { Regular laparoscopic } \\
\text { instruments } \\
\text { No catheters } \\
\text { Single stitch }\end{array}$ & 32 & 37.7 & 200 & 59 & 89 & 21 \\
\hline Barjot $1999^{4}$ & $\begin{array}{l}\text { Regular laparoscopic } \\
\text { instruments } \\
\text { Catheters } \\
\text { Three stitches }\end{array}$ & 14 & 35.5 & NR & 36 & 80 & 0 \\
\hline Bissonette $1999^{10}$ & $\begin{array}{l}\text { Regular laparoscopic } \\
\text { instruments } \\
\text { No catheters } \\
\text { Single stitch }\end{array}$ & 88 & 33.3 & 71 & 73 & 93 & 22 \\
\hline Yoon $1999^{11}$ & $\begin{array}{l}\text { Microsurgical instruments } \\
\text { No catheters }\end{array}$ & 186 & 35 & 140 & 85 & 97 & 16 \\
\hline Cha $2001^{12, c}$ & $\begin{array}{l}\text { Microsurgical instruments } \\
\text { No catheters }\end{array}$ & 36 & 35.7 & 202 & 81 & 97 & NR \\
\hline Hawkins $2002^{13, c}$ & $\begin{array}{l}\text { Microsurgical instruments } \\
\text { No catheters }\end{array}$ & 41 & NR & 103 & 65 & 88 & NR \\
\hline Goldberg $2003^{14}$ & $\begin{array}{l}\text { Microsurgical instruments } \\
\text { No catheters }\end{array}$ & 9 & 35.1 & 241 & 33 & 100 & 67 \\
\hline Ribeiro $2004^{15}$ & $\begin{array}{l}\text { Regular laparoscopic } \\
\text { instruments } \\
\text { Microsurgical stitches } \\
\text { No catheters }\end{array}$ & 23 & 34 & NR & 57 & 100 & 8 \\
\hline Wiegerinck $2005^{16}$ & $\begin{array}{l}\text { Microsurgical instruments } \\
\text { Microclips } \\
\text { Tissue glue }\end{array}$ & 41 & 34.9 & 212 & 49 & 95 & 20 \\
\hline Schepens $2011^{17}$ & $\begin{array}{l}\text { Microsurgical instruments } \\
\text { Microclips } \\
\text { Tissue glue }\end{array}$ & 127 & 35.7 & 148 & 74 & 96 & 20 \\
\hline Deffieux X $2011^{18, d}$ & $\begin{array}{l}\text { Laparoscopy } \\
\text { Laparotomy }\end{array}$ & $\begin{array}{r}484 \\
2766\end{array}$ & 35 & NR & $\begin{array}{l}31-85 \\
54-88\end{array}$ & $\begin{array}{r}93-100 \\
88-98\end{array}$ & $\begin{array}{l}0-11 \\
0-22\end{array}$ \\
\hline
\end{tabular}


Table 1 Continued.

\begin{tabular}{|c|c|c|c|c|c|c|c|}
\hline $\begin{array}{l}\text { First author, year, } \\
\text { reference number }\end{array}$ & Technique & $\begin{array}{l}\text { Number } \\
\text { of } \\
\text { patients }^{a}\end{array}$ & $\begin{array}{l}\text { Mean } \\
\text { age, } \\
\text { years }\end{array}$ & $\begin{array}{l}\text { Mean } \\
\text { operating } \\
\text { time, } \\
\text { minutes }\end{array}$ & $\begin{array}{l}\text { Total } \\
\text { pregnancy } \\
\text { rate, } \%\end{array}$ & $\begin{array}{l}\text { Intrauterine } \\
\text { pregnancy } \\
\text { rate, } \%\end{array}$ & $\begin{array}{l}\text { Abortion } \\
\text { rate, \% }\end{array}$ \\
\hline Jhui Ai $2011^{20}$ & Microsurgical instruments & 58 & 33 & 75 & 74 & 69 & 7 \\
\hline Tan HH $2010^{21, c}$ & $\begin{array}{l}\text { Regular laparoscopic } \\
\text { instruments } \\
\text { No catheters, no glue }\end{array}$ & 9 & $36^{e}$ & $221-168$ & 78 & NR & 33 \\
\hline \multicolumn{8}{|l|}{ With robot } \\
\hline Goldberg $2003^{14}$ & $\begin{array}{l}\text { Microsurgical instruments } \\
\text { No catheters }\end{array}$ & 10 & 31.1 & 365 & 50 & 100 & 0 \\
\hline Rodgers $2007^{22, c}$ & $\begin{array}{l}\text { Microsurgical instruments } \\
\text { No catheters }\end{array}$ & 23 & 34.2 & 229 & 61 & 89 & 16 \\
\hline $\begin{array}{c}\text { Dharia Patel } \\
2008^{23, c}\end{array}$ & $\begin{array}{l}\text { Microsurgical instruments } \\
\text { No catheters }\end{array}$ & 18 & 30.9 & 201 & 63 & 64 & 18 \\
\hline Caillet M $2010^{24}$ & $\begin{array}{l}\text { Microsurgical instruments } \\
\text { No catheters }\end{array}$ & 97 & 37 & $110^{f}$ & 71 & NR & NR \\
\hline
\end{tabular}

anly those included in analysis of pregnancy rates

${ }^{\text {bNot reported }}$

'Only laparoscopic procedures

dReview of 23 studies

excluding patients aged $\geq 40$ years

${ }^{f}$ After learning curve

76 had a follow-up of at least 12 months ${ }^{14}$. The duration of surgery per laparotomiam was significantly shorter (149 minutes vs. 202 minutes) but the hospital stay related to that approach was significantly longer than for the laparoscopic procedure (6.1 vs. 3.3 days). Pregnancy rates were similar: $77 \%$ in both groups.

The authors concluded that the same high success rate can be reached when performing a laparoscopy as compared to laparotomy provided the same microsurgical principles apply. Hawkins et al. compared the cost of tubal sterilisation reversal via laparoscopy with that of the procedure when done via laparotomy ${ }^{15}$. They concluded that the former approach was less expensive while yielding the same cumulative PR (65\%) as the latter.

\section{Our own findings and interpretation thereof}

Until 2002 we routinely performed tubal reanastomosis via laparotomy, using the microsurgical technique. In 2002, having acquired sufficient experience in laparoscopic surgery, we switched to a minimally invasive approach with which we achieve a PR of $66 \%$. This is somewhat lower than the PR reported by Yoon et al., obtained after extensive experience with the microsurgical laparoscopic technique ${ }^{13}$. It is however equal to- or exceeds PRs reported by other teams applying simplified laparoscopic techniques ${ }^{4,11,12}$. We must take into account that Dubuisson and Chapron ${ }^{11}$ and Barjot et al. ${ }^{4}$ reported on quite a small series of patients, and in these complex laparoscopic interventions there is undoubtedly an important effect of the learning curve. We agree with Barjot et al. who state that the use of tubal catheters facilitates correct alignment and suturing of the tubal ends ${ }^{4}$. Intraluminal damage is presumably minimal when manipulation is gentle.

Thirty-six percent of pregnancies in our study group ended in a miscarriage, a figure which is higher than that reported by other authors. This high abortion rate does not seem to be related to the average age of the patients treated (35 years). Indeed, the mean age of the women treated by Yoon and his team was the same ${ }^{13}$. Furthermore, we found no difference in abortion rates between the women younger than 40 and those aged 40 and more, but this could be due to the small number of pregnancies in the older age group. Our ectopic pregnancy rate, which could serve as an 
alternative marker for the quality of tubal patency, does not differ from that of most other series.

Sixty-six percent of all tubes proved to be patent on HSG. However, we must take into account the relatively low sensitivity of HSG after recanalisation, demonstrated by the fact that one patient had an ongoing intrauterine pregnancy while - seemingly - showing a bilateral block on HSG. In the last decade several reports of robot-assisted laparoscopic tubal sterilisation reversal procedures have been published. The PRs in these series are not better than those obtained via laparotomy nor those reported after a microsurgical laparoscopic intervention. Moreover, our PR as well as the mean stay in the hospital (less than 24 hours in all patients) are comparable to those reported for robotically assisted laparoscopic microsurgical tubal reanastomosis. The laparoscopic route for this type of surgery is more costeffective than laparotomy ${ }^{15}$, but a direct cost-effectiveness study comparing robotically assisted and classic laparoscopic recanalisation is lacking. However, the price of robotical tubal reversal equalling or being higher than that of an open procedure ${ }^{25,26}$, we claim that, for tubal sterilisation reversal, a classic laparoscopic approach, such as the one we use, is more cost-effective than any robotassisted technique.

\section{Strengths and weaknesses of the study}

Our cohort study, with a retrospective design, involves 100 cases, but lacks a control group. Its strength is that it describes a large series of patients and that the number of those lost to follow-up is small (6\%). Even if, among the latter, all women aged 40 or more and none of those who were younger would have conceived, the pregnancy rate would still be significantly higher in the age group under 40 years.

Although proposed as a standard assessment after surgery, only $78 \%$ of our patients underwent a HSG. This can be explained by the fact that most of these women are referred to us from other hospitals. We give them the opportunity to undergo the HSG at a hospital closer to home, which makes it harder to ensure adequate follow-up.

\section{Relevance of the findings: Implications for clinicians and policymakers}

Although the patients reported on in this paper are not directly comparable to those with tubal factor infertility treated in our centre of reproductive medicine, our technique of tubal reanastomosis yields a clinical pregnancy rate of $66 \%$ while that achieved per cycle in patients who underwent IVF was $23 \%$. This strengthens our opinion that all sterilised women can benefit from a laparoscopic approach for their reversal procedure. Also, in addition to being less costly, PRs achieved with tubal reanastomosis in women younger than 38 are significantly higher than after $\operatorname{IVF}^{27}$. Since the technique of tubal repair we have described can be performed by any experienced laparoscopic surgeon, using only classic laparoscopic $5 \mathrm{~mm}$ instruments and 4/0 polyglycan suture material, it is suitable for all women desiring children after sterilisation.

\section{Unanswered questions and future research}

On theoretical grounds one might think that the effectiveness (including cost-effectiveness) of laparoscopic tubal reanastomosis and IVF could be objectively compared in a randomised clinical trial involving sterilised women ${ }^{3}$. Yet such a study-design would be quite cumbersome. First of all, random allocation of participants to either group would be hardly feasible. Next, the trial would necessarily involve multiple centres and the standardisation of techniques and differences in surgical and/or laboratory expertise would be troublesome. Finally, over the past two decades, the increased use of IVF resulted in the loss of surgical expertise, making it difficult to find enough centres with sufficient expertise in both IVF and laparoscopic salpingoplasty.

\section{A C K N O W L E D G E M E N T S}

Kelly Tilleman informed us about the pregnancy rates achieved by the Ghent University Hospital Division of Reproductive Medicine.

Declaration of interest: The authors report no conflicts of interest. The authors alone are responsible for the content and the writing of the paper.

No funding was received for this study but P.D.S. holds a fundamental clinical research mandate granted by the Flemish Foundation of Scientific Research (FWO-Vlaanderen). 


\section{R E F E R E N C E S}

1. Wilcox LS, Chu SY, Eaker ED, et al. Risk factors for regret after tubal sterilization: 5 years of follow-up in a prospective study. Fertil Steril 1991;55:927-33.

2. Siegler AM, Hulka J, Peretz A. Reversibility of female sterilization. Fertil Steril 1985;43:499-510.

3. George K, Kamath MS, Tharyan P. Minimally invasive versus open surgery for reversal of tubal sterilization. Cochrane Database Syst Rev 2013;2:CD009174.

4. Barjot PJ, Marie G,Von Theobald P. Laparoscopic tubal anastomosis and reversal of sterilization. Hum Reprod 1999;14:1222-5.

-5. Dindo D, Demartines N, Clavien PA. Classification of surgical complications: a new proposal with evaluation in a cohort of 6336 patients and results of a survey. Ann Surg 2004;240:205-13.

-6. Zegers-Hochschild F, Adamson GD, de Mouzon J, et al. International Committee for Monitoring Assisted Reproductive Technology (ICMART) and the World Health Organization (WHO) revised glossary of ART terminology, 2009. Fertil Steril 2009;92:1520-4.

7. Gauwerky JF, Klose R. An experimental model for pelviscopic tubal anastomosis. Hum Reprod 1990;5:439-43.

-8. Reich H, McGlynn F, Parente C, et al. Laparoscopic tubal anastomosis. J Am Assoc Gynecol Laparosc 1993;1:16-9.

9. Koh $\mathrm{CH}$. Microsurgical laparoscopic tubal resection and anastomosis: technique and results. Références Gynécol Obstét 1995;Special issue:102-4.

10. Yoon TK, Sung HR, Cha SH, et al. Fertility outcome after laparoscopic microsurgical tubal anastomosis. Fertil Steril 1997;67:18-22.

11. Dubuisson JC, Chapron C. Single suture laparoscopic tubal re-anastomosis. Curr Opin Obstet Gynecol 1998;10:307-13.

12. Bissonnette F, Lapensée L, Bouzayen R. Outpatient laparoscopic tubal anastomosis and subsequent fertility. Fertil Steril 1999;72:549-52.

13. Yoon TK, Sung HR, Kang HG, et al. Laparoscopic tubal anastomosis: fertility outcome in 202 cases. Fertil Steril 1999;72:1121-6.

14. Cha SH, Lee MH, Kim JH, et al. Fertility outcome after tubal anastomosis by laparoscopy and laparotomy. $\mathrm{J} \mathrm{Am}$ Assoc Gynecol Laparosc 2001;8:348-52.
15. Hawkins J, Dube D, Kaplow M, Tulandi T. Cost analysis of tubal anastomosis by laparoscopy and by laparotomy. J Am Assoc Gynecol Laparosc 2002;9:120-4.

16. Goldberg JM, Falcone T. Laparoscopic microsurgical tubal anastomosis with and without robotic assistance. Hum Reprod 2003;18:145-7.

17. Ribeiro SC, Tormena RA, Giribela CG, et al. Laparoscopic tubal anastomosis. Int $J$ Gynecol Obstet 2004;84:142-6.

18. Wiegerinck MA, Roukema M, van Kessel P, Mol BW. Sutureless re-anastomosis by laparoscopy versus microsurgical re-anastomosis by laparotomy for sterilization reversal: a matched cohort study. Hum Reprod 2005;20:2355-8.

19. Schepens JJ, Mol BW, Wiegerinck MH, et al. Pregnancy outcomes and prognostic factors from tubal sterilization reversal by sutureless laparoscopical re-anastomosis: a retrospective cohort study. Hum Reprod 2011;26:354-9.

20. Deffieux X, Morin Surroca M, Faivre E, et al. Tubal anastomosis after tubal sterilization: a review. Arch Gynecol Obstet 2011;283:1149-58.

-21. Trimbos-KemperTC. Reversal of sterilization in women over 40 years of age: a multicenter survey in the Netherlands. Fertil Steril 1990;53:575-7.

22. Jihui Ai, Pei Zhang, Lei Jin, et al. Fertility outcome analysis after modified laparoscopic microsurgical tubal anastomosis. Front Med 2011;5:310-4.

23. Tan HH, Loh SF. Microsurgical reversal of sterilization - is this still clinically relevant today? Ann Acad Med Singapore 2010;39:22-6.

24. Rodgers AK, Goldberg JM, Hammel JP, Falcone T. Tubal anastomosis by robotic compared with outpatient minilaparotomy. Obstet Gynecol 2007;109:1375-80.

-25. Dharia Patel SP, Steinkampf MP,Whitten SJ, Malizia BA. Robotic tubal anastomosis: surgical technique and cost effectiveness. Fertil Steril 2008;90:1175-9.

26. Caillet M,Vandromme J, Rozenberg S, et al. Robotically assisted laparoscopic microsurgical tubal reanastomosis: a retrospective study. Fertil Steril 2010;94:1844-7.

27. Boeckxstaens A, Devroey P, Collins J, Tournaye H. Getting pregnant after tubal sterilization: surgical reversal or IVF? Hum Reprod 2007;22:2660-4. 